\title{
The Accession of the European Union to the European Convention on Human Rights
}

The draft Agreement on the Accession of the European Union to the European Convention on Human Rights - a major step towards a coherent protection of fundamental rights in Europe

\section{Introduction}

The accession of the European (Economic) Community, and later of the European Union (EU), to the European Convention on Human Rights (the Convention) has been called for since a long time. ${ }^{1}$ At the outset, the Community did not dispose of its own catalogue of fundamental rights, but the European Court of Justice (today Court of Justice, ECJ) soon closed that gap by developing a protection of human rights in its case-law. ${ }^{2}$ Despite this, the European Commission called for the accession of the European Economic Community to the Convention as early as $1979 .{ }^{3}$

When the EU Charter of Fundamental Rights was drawn up, the adoption of a legally binding Charter and EU accession to the Convention were considered by many not as alternatives, but as complementary steps. ${ }^{4}$ But it was not before the entry into force of the Lisbon Treaty on 1 December 2009 that it was decided that the EU shall accede to the Convention.

\section{Reasons for accession}

The accession of the EU to the Convention has always been called for in order to pursue three main objectives. Firstly, it shall ensure a coherent application of human rights and limit the divergences in the interpretation of the same fundamental rights by the European Court of Human Rights (ECtHR) and the Court of Justice of the European Union

1 See, for instance, G. Ress, L'adhésion de l'Union européenne à la Convention européenne des droits de l'homme, in: Dalloz (editor), La conscience des droits, Mélanges en l'honneur de Jean-Paul Costa, 2011, pp. 519 s.

2 See for a description of that development and further references, among many others, $D$. von Arnim, Der Standort der EU-Grundrechtecharta in der Grundrechtsarchitektur Europas, 2006, pp. 36-43.

3 In a memorandum of 4 April 1979 the Commission proposed that what was then still called the European Communities should accede to the Convention (see EuGRZ 1979, p. 330).

4 See, for example, L. Wildhaber /J. Callewaert, Espace constitutionnel européen et droits fondamentaux - Une vision globale pour une pluralité de droits et de juges, in : N. Colneric / D. Edward and others (editors), Une communauté de droit, Essays in honour of Gil Carlos Rodríguez Iglesias, 2003, p. 82; and von Arnim, Standort der EU-Grundrechtecharta, ibid., p. 516 with further references. 
(CJEU). ${ }^{5}$ There may be a higher risk of such divergences since the entry into force, together with the Lisbon Treaty, of the EU Charter of Fundamental Rights. It is true that Article $52 \S 3$ of that Charter stipulates that Charter rights which correspond to rights guaranteed by the Convention shall be interpreted in the same way as the Convention right concerned. However, this leads to the Convention being interpreted, directly or indirectly, both by the ECtHR and the CJEU.

Secondly, accession shall allow the EU to be a party to the proceedings before the ECtHR and to defend itself, including when the ECtHR rules on alleged human rights violations resulting from the application or implementation of EU law by its Member States. Moreover, it shall avoid problems in the execution of the ECtHR's judgments finding a violation of Convention rights caused by EU law. ${ }^{6}$

Thirdly, accession shall strengthen the protection of human rights and enhance the credibility of the EU's commitment to fundamental rights protection, vis-à-vis its citizens and vis-à-vis third countries, which it regularly requests to abide by the rights guaranteed by the Convention, by submitting the EU's legal order to the same external judicial control as the acts of its Member States. ${ }^{7}$ This is important in view of the fact that the EU Member States have transferred substantial powers to the EU. ${ }^{8}$

\section{Legal basis of accession}

It resulted from Opinion 2/94 of the Court of Justice of the European Communities (ECJ) of 28 March 1996 that the European Community did not have the competence to accede

5 See, for instance, O. De Schutter, L'adhésion de l'Union européenne à la Convention européenne des droits de l'homme: feuille de route de la négotiation, 10/04/2010, p. 5; M. O'Boyle, The Future of the European Court of Human Rights, GLJ, vol. 12, 2011, p. 1875. Compare also the Preamble to the Draft Agreement on the Accession of the European Union to the Convention for the Protection of Human Rights and Fundamental Freedoms, contained in the $\mathrm{CDDH}$ Report to the Committee of Ministers on the elaboration of legal instruments for the accession of the European Union to the European Convention on Human Rights, doc. CDDH(2011)009 of 14 October 2011, Appendix I, available of the CoE's Internet Site (http:// www.coe.int/t/dghl/standardsetting/hrpolicy/CDDH-UE/CDDH-UE_documents_en.asp).

6 See $F$. Tulkens, Les aspects institutionnels de l'adhésion de l'Union européenne à la Convention européenne de sauvegarde des droits de l'homme et des libertés fondamentales, Hearing on 18 March 2010 by the Committee on Constitutional Affairs of the European Parliament, p. 2; and F. Tulkens, Pour et vers une organisation harmonieuse, RTD eur. 47 (1), 2011, p. 28.

7 See European Parliament Resolution of 19 May 2010 on the institutional aspects of the accession of the European Union to the European Convention for the Protection of Human Rights and Fundamental Freedoms (2009/2241(INI)), §§ 1, 18, 21; Tulkens, Les aspects institutionnels de l'adhésion de UE à la CEDH, ibid., pp. 2/3; Tulkens, RTD eur. 47 (1), 2011, p. 28; and $J$. Callewaert, Accession by the EU to the European Convention on Human Rights: Some Practical Issues, ERA, Trier, 23 April 2010, p. 1. Compare also the Preamble to the Draft Agreement on the Accession of the European Union to the Convention for the Protection of Human Rights and Fundamental Freedoms, ibid., doc. CDDH(2011)009 of 14 October 2011, Appendix I.

8 See Draft Explanatory Report to the Accession Agreement, doc. CDDH(2011)009 of 14 October 2011, Appendix III, $\S 5$. 
to the Convention under the Treaties as they stood at that time. ${ }^{9}$ The Treaty of Lisbon, which entered into force on 1 December 2009, then provided for such competence. Article $6 \S 2$ of the consolidated version of the Treaty on European Union (TEU) now provides that the Union, which succeeded the European Community and has been given legal personality (Articles 1 and 47 TEU), "shall accede" to the Convention. The accession thus became a legal obligation. ${ }^{10}$

Since the entry into force of Protocol no. 14 to the Convention on 1 June 2010, the Convention, for its part, contains a legal basis for accession as its Article $59 \S 2$ now provides that the "European Union may accede to this Convention".

The political question of whether the EU should accede to the Convention is thus settled after some thirty years of discussion. ${ }^{11}$

\section{Procedure of accession}

The Committee of Ministers (CM) of the Council of Europe (CoE) adopted, on 26 May 2010, ad hoc terms of reference for its Steering Committee for Human Rights (CDDH) to elaborate, in co-operation with the representatives of the EU, the legal instrument(s) setting out the modalities of accession of the EU to the Convention. ${ }^{12}$ The CDDH established an informal working group, composed of 14 experts from the CoE Member States ( 7 members from EU Member States and 7 from non-Member States of the EU), to that end; a representative of the Registry of the ECtHR was entitled to participate in the meetings of the group as observer. ${ }^{13}$ The draft legal instruments setting out the modalities of accession were to be submitted to the CM no later than 30 June $2011 .{ }^{14}$ The Council of the EU, by a decision of 4 June 2010, authorised the European Commission to negotiate an accession agreement on behalf of the EU. ${ }^{15}$ These decisions, adopted speedily after the entry into force of the Lisbon Treaty and of Protocol no. 14 to the

9 ECR 1996, pp. I-1759 et seq. (1787-1789). See on this point also V. Skouris, First thoughts on the forthcoming accession of the European Union to the European Convention on Human Rights, in: D. Spielmann / M. Tsirli / P. Voyatzis (editors), The European Convention on Human Rights, a living instrument, Essays in Honour of Christos L. Rozakis, 2011, p. 556.

10 See also the Draft Explanatory Report to the Accession Agreement, doc. CDDH(2011)009 of 14 October 2011, Appendix III; O'Boyle, GLJ, vol. 12, 2011, p. 1875; and S. LeutheusserSchnarrenberger, Der Beitritt der EU zur EMRK: Eine schier unendliche Geschichte, in: C. Hohmann-Dennhardt / P. Masuch / M. Villiger (editors), Grundrechte und Solidarität, Festschrift für Renate Jaeger, 2011, p. 136.

11 See for the historical background and the course of the discussions, inter alia, LeutheusserSchnarrenberger, Beitritt der EU zur EMRK, ibid., pp. 136-144.

12 See Ad hoc terms of reference concerning accession of the EU to the Convention given to the CDDH by the Ministers' Deputies during their $1085^{\text {th }}$ meeting (26 May 2010), doc. CD$\mathrm{DH}(2010) 008$.

13 See Report of the Bureau of the CDDH of its $80^{\text {th }}$ meeting on 20-21 May 2010, doc. CDDHBU(2010)002, pp. 8-9; and Draft Explanatory Report to the Accession Agreement, doc. CDDH(2011)009 of 14 October 2011, Appendix III, § 13.

14 See Ad hoc terms of reference (ibid.), doc. $\operatorname{CDDH}(2010) 008$, pp. 1, 2.

15 See the (only partly declassified) document of the Council of the EU, no. 10817/10, FREMP 27 JAI 523 COHOM 153 COSCE 17, Annex I, Article 2; Draft Explanatory Report to the Accession Agreement, doc. CDDH(2011)009 of 14 October 2011, Appendix III, § 12. 
Convention, demonstrate that the accession procedure is being given priority both by the Council of Europe and by the EU. ${ }^{16}$

Following the opening of the negotiations of the EU accession to the Convention, the representatives of the $\mathrm{CoE}$ and of the EU quickly agreed to lay down the necessary provisions allowing for the accession in an accession agreement. ${ }^{17}$ In fact, even after the amendments made by Protocol no. 14 notably to $\S 2$ of Article 59 of the Convention, the Convention was still drafted to apply only to States who were also Member States of the Council of Europe. The EU, however, is neither a State nor is it to become a Member of the Council of Europe and has a specific legal system. Therefore, it was common ground that its accession required certain adaptations to the Convention system. ${ }^{18}$

The CDDH informal working group (CDDH-UE) met with the European Commission eight times between July 2010 and June 2011. It presented the elaborated Draft Accession Agreement, consisting of twelve Articles, and the explanatory report to the Agreement, together with a Draft Rule to be added to the Rules of the CM for the supervision of the execution of the ECtHR's judgments, to the CDDH in July 2011. ${ }^{19}$ The CDDH, having discussed but not yet adopted the draft legal instruments for the EU's accession to the Convention in its extraordinary meeting of 12-14 October 2011, transmitted the finalized instruments to the Committee of Ministers of the Council of Europe for consideration and further guidance. ${ }^{20}$ As some EU Member States still have reservations notably concerning the co-respondent mechanism, a further revision of the Draft Accession Agreement of 14 October 2011 cannot be completely excluded. ${ }^{21}$

16 See on this issue also Skouris, First thoughts on the forthcoming accession of the EU to the ECHR, Essays in Honour of Rozakis, ibid., pp. 559-561.

17 Leutheusser-Schnarrenberger, Beitritt der EU zur EMRK, ibid., p. 145.

18 See the Explanatory Report to Protocol no. 14 to the Convention, CETS no. 194, explanations in respect of Article 17 of the amending protocol, $\S \S 101-102$; and Draft Explanatory Report to the Accession Agreement, doc. CDDH(2011)009 of 14 October 2011, Appendix III, § 3. An accession treaty concluded between the EU and the State Parties to the Convention was considered preferable to agreeing on an amending Protocol to the Convention making the necessary changes to the Convention, followed by the EU's accession to the amended Convention; see for these options the Study of technical and legal issues of a possible EC/EU accession to the European Convention on Human Rights, report adopted by the CDDH of the Council of Europe on 28 June 2002, doc. DG-II(2002)006, pp. 3-7 (§§ 1-20); and De Schutter, L'adhésion de l'UE à la CEDH, ibid., pp. 3-4.

19 See Report of the $8^{\text {th }}$ working meeting of the CDDH informal working group on the accession of the European Union to the European Convention on Human Rights (CDDH-UE) with the European Commission, doc. CDDH-UE(2011)16 of 19 July 2011, available of the CoE's Internet, Site (http://www.coe.int/t/dghl/standardsetting/hrpolicy/CDDH-UE/CDDH-UE_ documents_en.asp); and CDDH Report to the Committee of Ministers on the elaboration of legal instruments for the accession of the European Union to the European Convention on Human Rights, doc. CDDH(2011)009 of 14 October 2011, §§ 6-7, equally available on the CoE's Internet Site (ibid.).

20 See doc. CDDH(2011)009 of 14 October 2011, ibid., §§ 9-15.

21 See for this assessment X. Groussot / T. Lock/L. Pech, EU Accession to the European Convention on Human Rights: a Legal Assessment of the Draft Accession Agreement of $14^{\text {th }}$ October 2011, in: Fondation Robert Schuman (editor), European Issues, $n^{\circ} 218$ of 7 November 2011, p. 16. 
The Draft Accession Agreement is to be approved by the CDDH. The Parliamentary Assembly of the Council of Europe (PACE) shall then express an opinion on it. The agreement shall subsequently be adopted by the $\mathrm{CM}$ and be opened for signature. ${ }^{22}$ It must be signed by the EU and the 47 Contracting Parties to the Convention.

The EU must then ratify the Accession Agreement in accordance with the rules laid down in Article $218 \S \S 6$ and 8 of the Treaty on the Functioning of the European Union (TFEU). That Article lays down the procedure for the conclusion of agreements between the EU and third countries or international organizations. It provides that the agreement on Union accession to the Convention shall be adopted by a unanimous decision of the Council of the EU after having obtained the consent of the European Parliament (EP). This decision shall enter into force after it has been approved by the EU Member States in accordance with their respective constitutional requirements. ${ }^{23}$ The CJEU may be involved in this procedure as under Article $218 \S 11$ TFEU, it may be asked for an opinion as to whether the Draft Accession Agreement is compatible with the EU treaties. ${ }^{24}$

Likewise, the 47 Contracting Parties to the Convention (including the 27 EU Member States) must ratify the Accession Agreement in compliance with their respective constitutional requirements. $^{25}$

The Draft Accession Agreement shall enter into force on the first day of the month following the expiration of a period of three months after the date on which all High Contracting Parties to the Convention at the date of the opening for signature of the Agreement and the European Union have expressed their consent to be bound by the Agreement (see Article $10 \S 3$ of the Agreement). The European Union shall become a Party to the Convention, to the Protocol to the Convention and to Protocol no. 6 to the Convention on the date of entry into force of the Agreement. ${ }^{26}$

The procedure outlined above thus demonstrates that quite a number of steps remain to be taken before the EU becomes the $48^{\text {th }}$ Contracting Party to the Convention.

22 See Draft Explanatory Report to the Accession Agreement, doc. CDDH(2011)009 of 14 October 2011, Appendix III, § 15.

23 See on this procedure also Skouris, First thoughts on the forthcoming accession of the EU to the ECHR, Essays in Honour of Rozakis, ibid., p. 558.

24 J.P. Jacqué mentions that some EU Member States announced to submit to the CJEU a request for an opinion on the compatibility of the Accession Agreement with the EU treaties, see L'adhésion de l'Union européenne à la Convention européenne des droits de l'homme, RTD eur. 47 (1), 2011, p. 8. See also T. Lock, Walking on a tightrope: The Draft ECHR Accession Agreement and the Autonomy of the EU Legal Order, CML Rev. 2011, p. 1028.

25 See on this procedure also Groussot / Lock / Pech, Legal Assessment of the Draft Accession Agreement, ibid., European Issues n ${ }^{\circ} 218$ (7 November 2011), pp. 16-17; Skouris, First thoughts on the forthcoming accession of the EU to the ECHR, Essays in Honour of Rozakis, ibid., p. 559; and O'Boyle, GLJ, vol. 12, 2011, p. 1876.

26 See Article $10 \S 4$ of the Draft Accession Agreement, ibid., and Draft Explanatory Report to the Accession Agreement, doc. CDDH(2011)009 of 14 October 2011, Appendix III, Article $1, \S 16$ and Article 10, 91 . 


\section{The main features of the draft agreement on the accession of the EU to the conven-} tion $^{27}$

\section{Guiding principles for the Accession Agreement}

Under the Accession Agreement, the EU would, as a matter of principle, accede to the Convention on an "equal footing" with the other Contracting Parties to the Convention, with the same rights and the same obligations. ${ }^{28}$ The Convention is indeed, as expressed in its Preamble, based on the principle of equality of the Contracting Parties before the Convention. $^{29}$

Moreover, the current control mechanism under the Convention shall be preserved as far as possible. ${ }^{30}$ It has been acknowledged that, unlike the present Contracting Parties to the Convention, the EU is not a State, but a supranational organization with legal personality and a specific legal order, which represents acts or positions taken by its 27 Member States which are all likewise parties to the Convention. This necessitated certain adjustments to the Convention system, which will be discussed in more detail below. ${ }^{31}$ Nevertheless, the draft accession agreement aims at limiting the adaptations to the Convention system to what is strictly necessary for the purpose of the accession of the EU. ${ }^{32}$ In this connection, it is especially welcome that for the definition of the EU's status as a Contracting Party to the Convention, reference shall be made, in Article 59 $\S 2$ (b) of the Convention as amended by Article 1 of the Accession Agreement, to the Accession Agreement. This allowed limiting considerably the amendments which have to be made to the text of the Convention itself, ${ }^{33}$ thus preserving its highly readable nature.

These guiding principles comply, in particular, with one of the main objectives of the EU's accession to the Convention: the submission of the EU's legal order to the same

27 The draft accession agreement is available on the Council of Europe's website (http:// www.coe.int/t/dghl/standardsetting/hrpolicy/CDDH-UE/CDDH-UE_documents_en.asp).

28 See CDDH Report to the Committee of Ministers on the elaboration of legal instruments for the EU accession to the Convention, doc. $\mathrm{CDDH}(2011) 009$ of 14 October 2011, ibid., § 8, and Draft Explanatory Report to the Accession Agreement, ibid., Appendix III, § 7. See also C. Ladenburger, Vers l'adhésion de l'Union européenne à la Convention européenne des droits de l'homme, RTD eur. 47 (1), 2011, p. 21; and Groussot/Lock/Pech, Legal Assessment of the Draft Accession Agreement, ibid., European Issues n 218 (7 November 2011), p. 8.

29 Compare Loizidou v. Turkey (preliminary objections), 23 March 1995, § 77, Series A no. 310; Tulkens, Les aspects institutionnels de l'adhésion de UE à la CEDH, ibid., p. 2; Tulkens, RTD eur. 47 (1), 2011, p. 28; and Ladenburger, RTD eur. 47 (1), 2011, p. 21.

30 See CDDH Report to the Committee of Ministers on the elaboration of legal instruments for the EU accession to the Convention, doc. $\mathrm{CDDH}(2011) 009$ of 14 October 2011, ibid., § 8; and Draft Explanatory Report to the Accession Agreement, ibid., Appendix III, § 7.

31 See also the Preamble to the Draft Agreement on the Accession of the European Union to the Convention for the Protection of Human Rights and Fundamental Freedoms, ibid., doc. CDDH(2011)009 of 14 October 2011, Appendix I.

32 See CDDH Report to the Committee of Ministers on the elaboration of legal instruments for the EU accession to the Convention, doc. $\mathrm{CDDH}(2011) 009$ of 14 October 2011, ibid., § 8, and Draft Explanatory Report to the Accession Agreement, ibid., Appendix III, § 7.

33 See Draft Explanatory Report to the Accession Agreement, doc. CDDH(2011)009 of 14 October 2011, Appendix III, Article 1, § 20. 
external judicial control as the acts of its Member States. It was clear that strengthening the protection of human rights and enhancing the credibility of the EU's commitment to fundamental rights protection would only be possible if no changes were made in relation to the EU which would be perceived as granting the EU privileges compared to the other Contracting Parties to the Convention. ${ }^{34}$

Moreover, it is clear that accession is limited to obliging the institutions and bodies of the EU as a separate legal entity to abide by the rights set out in the Convention when acting within the sphere of the competences transferred to it (compare Article $6 \S 2$ TEU). In accordance with Article 2 of the Protocol (no. 8) relating to Article $6 \S 2$ TEU, the accession treaty shall therefore neither affect the scope of the Union's competences nor the distribution of competences between the EU and its Member States (principle of neutrality regarding Union powers). ${ }^{35}$ This shall be confirmed by Article $59 \S 2$ (c) of the Convention, as amended by Article $1 \S 2$ of the Draft Accession Agreement. ${ }^{36}$

It is further understood that the accession should not affect the existing rights and obligations of EU Member States in relation to the Convention (principle of neutrality regarding Member States' obligations). The same applies to the rights and obligations of States Parties to the Convention which are not members of the EU. ${ }^{37}$

Finally, the accession of the EU to the Convention shall ensure a coherent application of human rights and limit the risk of divergences in the interpretation of the same fundamental rights by the ECtHR and the CJEU. In order to limit that risk and to meet the said objective, a quick accession is desirable. ${ }^{38}$ The Draft Accession Agreement, which was elaborated by the representatives of the EU and of the CoE in a relatively short time (approximately one year), is an important step in that direction.

\section{Material scope of the accession and its consequences for the status of the EU and EU law in relation to the Convention}

a. Scope of the accession

Under Article 1 of the Draft Accession Agreement, the EU shall accede to the Convention, and also to Protocols nos. 1 and 6 to the Convention. ${ }^{39}$ The Union shall therefore initially accede only to the Protocols to the Convention which all EU Member States have ratified. An amendment to Article $59 \S 2$ to the Convention shall further enable the

34 See Callewaert, Accession by the EU to the Convention, ibid., p. 1; Tulkens, Les aspects institutionnels de l'adhésion de UE à la CEDH, ibid., p. 3; and Tulkens, RTD eur. 47 (1), 2011, p. 29.

35 See De Schutter, L'adhésion de l'UE à la CEDH, ibid., p. 7; and Ladenburger, RTD eur. 47 (1), 2011, p. 21. The implications of the principle of autonomous interpretation of Union law will be discussed below.

36 See also Draft Explanatory Report to the Accession Agreement, doc. CDDH(2011)009 of 14 October 2011, ibid., Appendix III, § 7 and Article 1, § 21.

37 See Draft Explanatory Report to the Accession Agreement, doc. CDDH(2011)009 of 14 October 2011, ibid., Appendix III, § 7; and Ladenburger, RTD eur. 47 (1), 2011, p. 21.

38 See Tulkens, Les aspects institutionnels de l'adhésion de UE à la CEDH, ibid., p. 2; and Tulkens, RTD eur. 47 (1), 2011, pp. 27-28.

39 Ibid., doc. CDDH(2011)009 of 14 October 2011, Appendix I. 
EU to accede to further Protocols, all of which are of potential relevance to the exercise of the Union's powers, by the deposit of separate accession instruments, that is, under the ordinary procedure foreseen by those Protocols (see Article $1 \S 2$ of the Draft Accession Agreement). ${ }^{40}$

The EU may further make reservations to the Convention and to the Protocols (to the extent that these permit reservations) just as may the other Contracting Parties, in accordance with Article 57 of the Convention. The latter provision, which refers to States, shall further be reformulated to provide for that possibility (see Article 2 of the Draft Accession Agreement).

\section{b. Technical adaptations to the Convention and to related agreements}

The Convention and its Protocols contain some references to "State(s)" (for example in Articles $10 \S 1$ and 17 of the Convention) or to State-related terms, such as "national" security / law(s) / authority, "nation", "country" or "domestic" (for instance in Articles $5-8,10-13,15$ and 35 of the Convention). Article $59 \S 2$ (d) and (e) of the Convention, as amended by Article $1 \S 2$ of the Draft Accession Agreement, shall provide that these terms shall be understood as also referring, or relating mutatis mutandis, to the EU. ${ }^{41}$ By that general interpretation clause, it is clarified that the terms concerned, listed in detail, by reference to the Convention Articles concerned, in the proposed new Article $59 \S 2$ (d) and (e) of the Convention, refer also to the Union. ${ }^{42}$

There is one important State-related term which has not been included in the above interpretation clause: the term "nationals" in Article 36 of the Convention. It was agreed that EU citizenship was not analogous to the concept of nationality referred to in Article 36 of the Convention. ${ }^{43}$ As a consequence, the EU will not have a right to intervene as

40 See Draft Explanatory Report to the Accession Agreement, doc. CDDH(2011)009 of 14 October 2011, Appendix III, Article 1, §§ 16, 19; and Groussot / Lock / Pech, Legal Assessment of the Draft Accession Agreement, ibid., European Issues n 218 (7 November 2011), p. 9.

41 Ibid., doc. CDDH(2011)009 of 14 October 2011, Appendix I, and Draft Explanatory Report to the Accession Agreement, doc. CDDH(2011)009 of 14 October 2011, Appendix III, Article $1, \S \S 22-24$.

42 See for further details the Draft Explanatory Report to the Accession Agreement, doc. CDDH(2011)009 of 14 October 2011, Appendix III, Article 1, § 25, and the complete table of all State-related expressions and their interpretation after the EU's accession at the end of that Explanatory Report. Only exceptionally, in relation to certain provisions, amendments to the text of the Convention itself have been made for reasons of legal certainty. In particular, Article $57 \S 1$ of the Convention, as to be amended in accordance with Article $2 \S 2$ of the Draft Accession Agreement, shall clarify that the EU may make reservations to the Convention under the same conditions as the other Contracting Parties (see the Draft Explanatory Report to the Accession Agreement, doc. CDDH(2011)009 of 14 October 2011, Appendix III, Article 2, §§ 27-30).

43 See Draft Explanatory Report to the Accession Agreement, doc. CDDH(2011)009 of 14 October 2011, Appendix III, Article 1, $\S 25$ and the appendix to that report. According to the CDDH Study on EU accession of 2002, ibid., p. 12 (§54), the term "nationals", on the contrary, covered EU citizens, and the EP Resolution of 19 May 2010 on EU accession to the Convention, ibid., § 13 made the same assumption. 
a third party in all proceedings before the ECtHR in which a national of an EU Member State (and thus a citizen of the Union, see Article $20 \S 1$ TFEU) is an applicant.

Furthermore, Article 9 of the Draft Accession Agreement provides that the EU shall respect and be treated as a Contracting Party to several agreements relating to the Convention system. These agreements concern privileges and immunities granted to judges of the ECtHR and to members of its registry, to persons taking part in the proceedings before the ECtHR, to States' representatives in the Committee of Ministers and to members of the Parliamentary Assembly. ${ }^{44}$

As regards, in particular, the above-mentioned State-related terms, it is in fact quite likely that the ECtHR would have interpreted these terms in the manner laid down in the Draft Accession Agreement in its subsequent case-law, had the above interpretative provisions not been included in the Accession Agreement. It is to be welcomed, however, that the Draft Accession Agreement opted, in principle, for a general interpretation clause instead of an amendment to all the relevant Articles of the Convention, together with those of the Protocols currently and potentially concerned. This again maintains the clarity and readability of the Convention text.

c. Consequences of the accession for the status of the EU and EU law in relation to the Convention (preservation of the Bosphorus case-law?)

Currently, the EU cannot be held responsible under the Convention for acts of its organs and applications brought against it are incompatible ratione personae with the Convention because it is not yet a Contracting Party to the Convention. ${ }^{45}$ On the contrary, its Member States remain responsible under Article 1 of the Convention for all acts of their organs even if these acts were a consequence of the necessity to comply with primary or secondary EU law. ${ }^{46}$

In order to reconcile the Member States' duty to comply both with their legal obligations flowing from their membership in an international organization and their obligations under the Convention, and having regard to the considerable interest of international cooperation, which the ECtHR wishes to support, the ECtHR, however, limited

44 This covers Articles 1 to 6 of the European Agreement relating to Persons Participating in Proceedings of the European Court of Human Rights of 5 March 1996 (ETS No. 161); Articles 1 to 19 of the General Agreement on Privileges and Immunities of the Council of Europe of 2 September 1949 (ETS No. 2) and Articles 2 to 6 of its Protocol of 6 November 1952 (ETS No. 10), in so far as they are relevant to the operation of the Convention; and Articles 1 to 6 of the Sixth Protocol to the General Agreement on Privileges and Immunities of the Council of Europe of 5 March 1996 (ETS No. 162), see Article 9 § 1 of the Draft Accession Agreement, ibid., and Draft Explanatory Report to the Accession Agreement, doc. CDDH(2011)009 of 14 October 2011, Appendix III, Article 9, §§ 89-90.

45 See C.F.D.T. v. the European Communities, alternatively their Member States, no. 8030/77, Commission decision of 10 July 1978, Decisions and Reports (DR) 13, pp. 236 et seq.; and Bosphorus Hava Yollarl Turizm ve Ticaret Anonim Şirketi v. Ireland [GC], no. 45036/98, $\S 152$, ECHR 2005-VI with further references.

46 Cantoni v. France, 15 November 1996, § 30, Reports of Judgments and Decisions 1996-V; Matthews v. the United Kingdom [GC], no. 24833/94, §§ 32-34, ECHR 1999-I; and Bosphorus, cited above, $\S 153$. See also Ress, L'adhésion de l'UE à la CEDH, Mélanges Costa, ibid., pp. 519 s., 522. 
its scrutiny of Convention compliance of Member States' action taken in accordance with their strict international legal obligations under EU law in its judgment in the Bosphorus case. ${ }^{47}$ It found that if the relevant international organization (here the EU) protects fundamental rights in a manner which can be considered at least equivalent (i.e. comparable) to that for which the Convention provides, there is a presumption that a State has not departed from the requirements of the Convention when it does no more than implement legal obligations flowing from its membership of the organization. ${ }^{48}$ The EU, and the CJEU in particular, which refers extensively to Convention provisions and to the ECtHR's case-law as part of the general principles of EU law, was found by the ECtHR to provide such an equivalent protection of fundamental rights. ${ }^{49}$ That presumption can be rebutted if, in the circumstances of a particular case, the protection of Convention rights was manifestly deficient. ${ }^{50}$ The ECtHR's Bosphorus case-law thus could be seen as granting a privileged position to the Union's legal order compared to those of the Contracting Parties to the Convention. ${ }^{51}$

Once it has become a Contracting Party to the Convention, the EU may itself be held responsible for acts of its organs. The question therefore arises whether the Bosphorus case-law will or should be upheld after accession.

On the one hand, one of the reasons of existence of the Bosphorus presumption, the need not to hamper international cooperation within the EU, a supranational organization, will not cease to exist after accession..$^{52}$ A restricted control of the compliance with fundamental rights of acts of international organizations is also often applied by States in relation to such organizations. ${ }^{53}$

On the other hand, upholding the presumption and thus granting a kind of privilege to the Union's legal order might appear to sit uneasily with the principle of equality of all Contracting Parties to the Convention, many of which have a record in applying the Convention which is just as good as that of the EU. ${ }^{54}$ It further raises questions as to its compatibility with two of the objectives of the Union's accession to the Convention, namely the objective of ensuring a coherent interpretation of human rights throughout Europe and that of enhancing the credibility of the EU's commitment to fundamental

47 Bosphorus, cited above, $\S \S 150$ and 152-155. See on this case-law also Ress, L'adhésion de l'UE à la CEDH, Mélanges Costa, ibid., pp. 522 ss.

48 Bosphorus, cited above, $\S \S 155-156$.

49 Bosphorus, cited above, $\S \S 159-165$.

50 Bosphorus, cited above, $\S 156$.

51 See, for instance, De Schutter, L'adhésion de l'UE à la CEDH, ibid., p. 6; and Groussot / Lock / Pech, Legal Assessment of the Draft Accession Agreement, ibid., European Issues n ○ 218 (7 November 2011), p. 9.

52 Compare Callewaert, Accession by the EU to the Convention, ibid., p. 6; Ress, L'adhésion de l'UE à la CEDH, Mélanges Costa, ibid., p. 522; and Tulkens, RTD eur. 47 (1), 2011, p. 29.

53 See Ress, L'adhésion de l'UE à la CEDH, Mélanges Costa, ibid., p. 525 with references to the German Federal Constitutional Court's case-law.

54 Compare T. Lock, The ECJ and the ECtHR: The Future Relationship between the Two European Courts, in: The Law and Practice of International Courts and Tribunals 8 (2009), pp. 395-396; J.P. Jacqué, L'adhésion à la Convention européenne des droits de l'homme, Hearing on 18 March 2010 by the Committee on Constitutional Affairs of the European Parliament, $\S 2$; Callewaert, Accession by the EU to the Convention, ibid., p. 6; and Tulkens, RTD eur. 47 (1), 2011, p. 29. 
rights protection by submitting its legal order to the same external judicial control as the acts of its Member States. ${ }^{55}$ Furthermore, under Article 1 of the Convention, all Contracting Parties to the Convention secure for everyone within their jurisdiction the rights and freedoms laid down in the Convention. If an international organization therefore accepts to be party to the Convention, it appears to accept to submit itself to an unrestricted control of the Convention compliance of its acts, like all States party to the Convention. ${ }^{56}$

The Draft Accession Agreement does not address the question of the much-discussed future of the Bosphorus case-law. This must be considered as a deliberate - and wise omission. At present, the Bosphorus jurisprudence is valid case-law of the ECtHR. It is for the ECtHR to ensure the observance of the engagements taken by the Contracting Parties in the Convention (Article 19 of the Convention). It is thus for that court alone to decide, when the time has come, whether or not the Bosphorus case-law shall be upheld in the new legal framework following the accession of the Union to the Convention. ${ }^{57}$

\section{Issues related to the procedure before the ECtHR}

a. Implications of the principle of autonomy of EU law

According to the principle of autonomy of EU law, which the CJEU deduces from Article $19 \S 1$ TEU and Article 344 TFEU, disputes concerning the interpretation or application of EU law may not be submitted to any external procedure of settlement, but must be settled in accordance with the methods of settlement provided for in the Treaties; the CJEU alone has to have the last word on the interpretation of primary and secondary EU law. ${ }^{58}$ The Union's concern to uphold this principle after its accession to the Convention is reflected in Article 1 of Protocol (no. 8) relating to Article $6 \S 2$ TEU and in the Declaration on Article $6 \S 2$ TEU, which stipulate that the accession agreement shall make provision for preserving the specific characteristics of Union law. ${ }^{59}$

However, that principle does not appear to be called into question by the EU's accession to the Convention even though its respect may necessitate certain adaptations in the procedure before the ECtHR.

First, the accession does not appear to infringe the CJEU's autonomy in the interpretation of the material provisions of EU law. It is true that the ECtHR, when determining, for instance, whether an act of a Union organ is "in accordance with the law", will have

55 See De Schutter, L'adhésion de l'UE à la CEDH, ibid., p. 6, and Groussot / Lock / Pech, Legal Assessment of the Draft Accession Agreement, ibid., European Issues n ${ }^{\circ} 218$ (7 November 2011), p. 9, who plead for abandoning the Bosphorus case-law after accession.

56 Ress, L'adhésion de l'UE à la CEDH, Mélanges Costa, ibid., p. 526.

57 Compare Callewaert, Accession by the EU to the Convention, ibid., p. 6; Tulkens, RTD eur. 47 (1), 2011, p. 29; and Ladenburger, RTD eur. 47 (1), 2011, p. 23.

58 See De Schutter, L'adhésion de l'UE à la CEDH, ibid., pp. 8, 9; and Groussot / Lock / Pech, Legal Assessment of the Draft Accession Agreement, ibid., European Issues n ${ }^{\circ} 218$ (7 November 2011), p. 10.

59 See also De Schutter, L'adhésion de l'UE à la CEDH, ibid., p. 8. 
to give its view on the content of the provisions of EU law at issue. ${ }^{60}$ However, when determining whether the act of a Contracting Party is compatible with the Convention, it is the ECtHR's consistent case-law that "it is primarily for the national authorities, notably the courts, to resolve problems of interpretation of domestic legislation" and that the "Court's role is confined to ascertaining whether those rules are applicable and whether their interpretation is compatible with the Convention". ${ }^{61}$ The ECtHR will thus base its findings as regards the content of the provisions of EU law at issue on the interpretation previously given to them by the CJEU. ${ }^{62}$ Moreover, from a public international law perspective, domestic law of the Contracting Parties is in principle no more than a fact. Therefore, the ECtHR, in determining whether an act of the Union complies with the Convention, will not give any authoritative interpretation of provisions of EU law and will, in particular, not rule on the validity of those provisions, ${ }^{63}$ the CJEU will remain the final authority in this respect. ${ }^{64}$

The principle of autonomy of EU law further requires that the CJEU alone is called upon to interpret the Treaty provisions on the distribution of competences between the Union and its Member States. This issue becomes relevant for the ECtHR when determining whether the defendant party in a case before it (the Union and / or one or several of its Member States) was responsible for the impugned situation in that it fell under its "jurisdiction", within the meaning of Article 1 of the Convention. ${ }^{65}$ The introduction of an instrument such as a co-respondent mechanism (see below), which ensures that the ECtHR will not be called upon to determine whether an act fell within the Union's or the Member States' exclusive competence or whether the competences were shared, shall be set up to solve this problem. ${ }^{66}$

Finally, the obligation under Article $46 \S 1$ of the Convention to abide by the final judgments of the ECtHR does not affect the principle of autonomy of EU law either. According to the ECtHR's well-established case-law, its judgments are essentially declaratory in nature and it is primarily for the Contracting Party concerned to choose the means to be used in its domestic legal order in order to discharge its legal obligation under Article 46 of the Convention, provided that such means are compatible with the conclusions set out in the ECtHR's judgment ${ }^{67}$ The ECtHR therefore neither annuls nor

60 See De Schutter, L'adhésion de l'UE à la CEDH, ibid., pp. 10-11.

61 See for a recent authority Neulinger and Shuruk v. Switzerland [GC], no. 41615/07, § 100, 6 July 2010 with further references.

62 See Groussot / Lock / Pech, Legal Assessment of the Draft Accession Agreement, ibid., European Issues n ${ }^{\circ} 218$ (7 November 2011), p. 10; and Skouris, First thoughts on the forthcoming accession of the EU to the ECHR, Essays in Honour of Rozakis, ibid., p. 569.

63 Draft Explanatory Report to the Accession Agreement, doc. CDDH(2011)009 of 14 October 2011, Appendix III, Article 3, $§ 54$. This is also stressed by Ress, L'adhésion de l'UE à la CEDH, Mélanges Costa, ibid., pp. 520-521; and Lock, CML Rev. 2011, pp. 1034-1036.

64 See De Schutter, L'adhésion de l'UE à la CEDH, ibid., p. 10.

65 See De Schutter, L'adhésion de l'UE à la CEDH, ibid., pp. 11/12.

66 See De Schutter, L'adhésion de l'UE à la CEDH, ibid., pp. 11/12.

67 See, inter alia, Assanidze v. Georgia [GC], no. 71503/01, § 202, ECHR 2004-II with further references. 
amends domestic legislation, measures or court decisions ${ }^{68}$ and can thus be said to act as a specialised fundamental rights court supervising compliance with the international law obligations of the EU resulting from accession rather than as a superior authority. ${ }^{69}$

\section{b. Introduction of a co-respondent mechanism}

The co-respondent mechanism is probably the most innovative element to be introduced by the Accession Agreement. The co-respondent (or co-defendant) mechanism is an arrangement ensuring that the EU and its Member State(s) may appear jointly as defendants before the ECtHR in cases concerning EU law. Article 3 of the Draft Accession Agreement provides that that mechanism shall be introduced alongside the third-party intervention provided for in Article 36 of the Convention. It shall apply to applications submitted from the date of entry into force of the Accession Agreement. ${ }^{70}$

Under the new paragraph 4 of Article 36 of the Convention, as amended by the Accession Agreement, the EU or an EU Member State may become a co-respondent to proceedings by decision of the ECtHR in the circumstances set out in the Accession Agreement. That provision further stipulates that a co-respondent shall be a party to the case and that the admissibility of an application shall be assessed without regard to the participation of a co-respondent in the proceedings.

\section{(1) Reasons for the introduction of a co-respondent mechanism}

A co-respondent mechanism was first proposed by the CoE's CDDH study on accession in 2002 as a means to adapt the Convention system to the specific nature of the EU, which is characterised by the fact that in many areas the competence to act is distributed in a complex manner between the EU and its Member States. ${ }^{71}$

In fact, it is a special feature of the EU legal system that acts, in particular secondary EU law, adopted by its institutions may be implemented by its Member States and, conversely, that provisions of the EU founding treaties (primary EU law) agreed upon by its Member States may be implemented by institutions of the EU. Therefore, following the accession of the EU to the Convention, the unique situation in the Convention system could arise in which a legal act is adopted by one Contracting Party and imple-

68 See De Schutter, L'adhésion de l'UE à la CEDH, ibid., pp. 15-16; Jacqué, L'adhésion à la CEDH, Hearing by the European Parliament, ibid., § 2; Groussot / Lock / Pech, Legal Assessment of the Draft Accession Agreement, ibid., European Issues n ${ }^{\circ} 218$ (7 November 2011), p. 10; and Lock, CML Rev. 2011, pp. 1036-1037.

69 See EP Resolution of 19 May 2010 on EU accession to the Convention, ibid., § 1.

70 See Article $3 \S 8$ of the Draft Accession Agreement, ibid.; and Draft Explanatory Report to the Accession Agreement, doc. CDDH(2011)009 of 14 October 2011, Appendix III, Article 3, $\S 56$. See for a good graphical illustration of the functioning of the co-respondent mechanism Groussot / Lock/Pech, Legal Assessment of the Draft Accession Agreement, ibid., European Issues $n^{\circ} 218$ (7 November 2011), p. 11.

71 See CDDH Study on EU accession of 2002, ibid., pp. 13-14 (§§ 57-62); and Callewaert, Accession by the EU to the Convention, ibid., p. 2. 
mented by another. ${ }^{72}$ Moreover, the Contracting Party implementing the provisions of (primary or secondary) EU law at issue does not have the competence to amend the legal provision at issue, adopted by the other Contracting Party, in cases where it is found to have been at the root of a Convention violation.

In the light of this, a co-respondent mechanism was considered necessary to accommodate that specific situation of the EU as a non-State entity with an autonomous legal system that is becoming a Party to the Convention alongside its own Member States. ${ }^{73}$ The need for such a mechanism was also expressed in Article 1 (b) of Protocol (no. 8) to the Treaty of Lisbon relating to Article $6 \S 2$ TEU, which stipulates that the accession agreement shall contain the necessary mechanisms to ensure that applications are correctly addressed to the Member States and / or the Union as appropriate. ${ }^{74}$ The co-respondent mechanism is aimed at ensuring that an application is directed against the respondent(s) responsible for and competent to put an end to an alleged Convention violation. $^{75}$

\section{(2) Functioning of the co-respondent mechanism}

The co-respondent mechanism comes into play in three situations.

Firstly, the European Union may become a co-respondent to the proceedings pending before the ECtHR concerning an application alleging a Convention violation which the ECtHR has communicated to the respondent Party. This is the case where an application is directed against one or more Member States of the EU, but it appears that the alleged Convention violation calls into question the compatibility with the Convention rights at issue of a provision of (primary or secondary) ${ }^{76}$ EU law.

This constellation concerns cases in which an EU Member State implemented obligations arising from either EU primary or secondary law and where the compatibility of the national implementing measures with the Convention was contested before the domestic courts. The alleged breach of the Convention can either stem directly from the content of the provisions of EU law itself or from the way in which they were implemented by the national authorities. ${ }^{77}$ In cases where the Convention violation could have been avoided only by disregarding an obligation under EU secondary law (for example, if the provision of EU law left no discretion to a Member State in respect of the manner of its implementation at domestic level), ${ }^{78}$ it would only be the EU which would be in

72 Draft Explanatory Report to the Accession Agreement, doc. CDDH(2011)009 of 14 October 2011, Appendix III, Article 3, §§ 32, 54. See also Groussot / Lock / Pech, Legal Assessment of the Draft Accession Agreement, ibid., European Issues n 218 (7 November 2011), p. 13.

73 See on the co-respondent mechanism also De Schutter, L'adhésion de l'UE à la CEDH, ibid., pp. 12-15.

74 See also the EP Resolution of 19 May 2010 on EU accession to the Convention, ibid., § 12.

75 See Ladenburger, RTD eur. 47 (1), 2011, p. 21.

76 Draft Explanatory Report to the Accession Agreement, doc. CDDH(2011)009 of 14 October 2011, Appendix III, Article 3, § 42.

77 See Groussot / Lock / Pech, Legal Assessment of the Draft Accession Agreement, ibid., European Issues $n^{\circ} 218$ (7 November 2011), p. 11.

78 Draft Explanatory Report to the Accession Agreement, doc. CDDH(2011)009 of 14 October 2011, Appendix III, Article 3, § 42. 
a position to afford redress by a change in that law if a Convention violation is found. ${ }^{79}$

Secondly, the EU Member States may become co-respondents to proceedings relating to an alleged Convention violation notified by the ECtHR. This shall be the case where an application is directed against the EU, but it appears that the alleged breach of the Convention calls into question the compatibility with the Convention rights at issue of a provision of EU primary law (the TEU, the TFEU or any other provision having the same legal value pursuant to those instruments). The co-respondent mechanism shall come into play in this constellation, in particular, where the Convention violation could have been avoided only by disregarding an obligation under EU primary law - which only the EU Member States, being the masters of the EU treaties, have the power to amend. ${ }^{80}$

Thirdly, the status of any respondent may be changed to that of a co-respondent at the request of either of the respondents where an application is directed against and notified to both the EU and one or more of its Member States and the above-mentioned conditions for the operation of the co-respondent mechanism are met. ${ }^{81}$ This is not the case if an applicant alleges different violations by the EU and one or more of its Member States separately. ${ }^{82}$

Whether or not the EU or one or more of its Member States become a co-respondent in proceedings before the ECtHR and the co-respondent mechanism is thus activated depends essentially on their own will. Neither the ECtHR nor the applicant or the respondent may oblige any of them to become a co-respondent in an application in which they were not initially designated as respondent. They shall become co-respondent(s) only at their own reasoned request made to the ECtHR. ${ }^{83}$ The ECtHR may, however, if appropriate, indicate that a party to the Convention may become a co-respondent on communication of the application to the respondent party. It is for the ECtHR to decide, after having consulted the parties to the proceedings, whether a Contracting Party's request to be made co-respondent shall be granted. The ECtHR shall grant such a request

79 See Article $3 \S 2$ of the Draft Accession Agreement, ibid.; and Groussot / Lock / Pech, Legal Assessment of the Draft Accession Agreement, ibid., European Issues n ${ }^{\circ} 218$ (7 November 2011), p. 12.

80 See Article $3 \S 3$ of the Draft Accession Agreement, ibid.; and Draft Explanatory Report to the Accession Agreement, doc. CDDH(2011)009 of 14 October 2011, Appendix III, Article 3, $\S 43$. See also Groussot / Lock / Pech, Legal Assessment of the Draft Accession Agreement, ibid., European Issues n ${ }^{\circ} 218$ (7 November 2011), pp. 12-13.

81 See Article $3 \S 4$ of the Draft Accession Agreement, ibid.; and Draft Explanatory Report to the Accession Agreement, doc. CDDH(2011)009 of 14 October 2011, Appendix III, Article 3, $\S 49$. See also Groussot / Lock / Pech, Legal Assessment of the Draft Accession Agreement, ibid., European Issues n 218 (7 November 2011), p. 12.

82 Draft Explanatory Report to the Accession Agreement, doc. CDDH(2011)009 of 14 October 2011, Appendix III, Article 3, § 38.

83 See also Groussot / Lock / Pech, Legal Assessment of the Draft Accession Agreement, ibid., European Issues $n^{\circ} 218$ (7 November 2011), pp. 11, 12 . 
if, in the light of the reasons given by the requesting Contracting Party, it is plausible that the above conditions for the operation of the co-respondent mechanism are met. ${ }^{84}$

The applicant cannot, therefore, force a party against which he did not initially direct his application to become a co-respondent or prevent that party from being joined to the proceedings. As, under the new paragraph 4 of Article 36 of the Convention, as amended by the Accession Agreement, the admissibility of an application shall be assessed without regard to the participation of a co-respondent in the proceedings, the application will not, however, be considered (partly) inadmissible for non-exhaustion of domestic remedies as a result of the participation of the co-respondent. ${ }^{85}$ Other than in the situation where the applicant named several respondents from the outset, the applicant therefore does not have to exhaust domestic remedies in the co-respondent's legal system. ${ }^{86}$

Having become a party to the case, the co-respondent shall appear jointly with the respondent in the proceedings before the ECtHR. ${ }^{87}$ They both need to agree to a friendly settlement or to make a unilateral declaration of a violation for which they are both responsible. ${ }^{88}$ If the ECtHR found a Convention violation, it is expected that it would ordinarily do so jointly and in solidarity against the respondent and the co-respon$\operatorname{dent}(\mathrm{s}) .{ }^{89}$ Otherwise, there would be a risk that the ECtHR would assess the distribution of competences between the EU and its Member States. The respondent and the corespondent(s) may, however, make joint submissions to the ECtHR that the responsibility for any given alleged violation should be attributed to only one of them. ${ }^{90}$ Under Article 43 of the Convention, both the respondent and the co-respondent(s), being parties to the case, may further request, unilaterally, the referral of a case to the Grand Chamber. ${ }^{91}$ Finally, the ECtHR may terminate the participation of a co-respondent at any stage of the proceedings, in particularshould it should receive a joint representation by the respondent and the co-respondent that the criteria for becoming a co-respondent are not, or no longer, met. ${ }^{92}$

It is further understood that the EU may still participate in proceedings before the ECtHR as a third-party intervener under Article $36 \S 2$ of the Convention if the condi-

84 See Article $3 \S 5$ of the Draft Accession Agreement, ibid.; and Draft Explanatory Report to the Accession Agreement, doc. $\mathrm{CDDH}(2011) 009$ of 14 October 2011, Appendix III, Article 3, $\S \S 45-48$.

85 Draft Explanatory Report to the Accession Agreement, doc. CDDH(2011)009 of 14 October 2011, Appendix III, Article 3, § 34.

86 Groussot/Lock/Pech, Legal Assessment of the Draft Accession Agreement, ibid., European Issues n 218 (7 November 2011), p. 11.

87 See Article $3 \S 7$ of the Draft Accession Agreement, ibid.

88 Draft Explanatory Report to the Accession Agreement, doc. CDDH(2011)009 of 14 October 2011, Appendix III, Article 3, §§ 52-53.

89 See also De Schutter, L'adhésion de l'UE à la CEDH, ibid., pp. 13 ss.; Callewaert, Accession by the EU to the Convention, ibid., p. 4; and Ladenburger, RTD eur. 47 (1), 2011, p. 25.

90 Draft Explanatory Report to the Accession Agreement, doc. CDDH(2011)009 of 14 October 2011, Appendix III, Article 3, § 54; see also Tulkens, RTD eur. 47 (1), 2011, pp. 30-31; and Ladenburger, RTD eur. 47 (1), 2011, p. 25.

91 Draft Explanatory Report to the Accession Agreement, doc. CDDH(2011)009 of 14 October 2011, Appendix III, Article 3, §55.

92 Draft Explanatory Report to the Accession Agreement, doc. CDDH(2011)009 of 14 October 2011, Appendix III, Article 3, § 51. 
tions for becoming a co-respondent are not met. This may notably be the case if an application is directed against a State associated to parts of the EU legal order through separate international agreements, such as the "Dublin" and "Schengen" agreements. 93

\section{(3) Assessment of the co-respondent mechanism}

The co-respondent mechanism has numerous advantages, in the first place, for the parties to the proceedings before the ECtHR. On the one hand, if it operates, there is no risk of the ECtHR finding a Convention violation against either the EU or its Member State(s), without the respondent being in a position to make the necessary amendments to the provisions of EU primary or secondary law at issue in order to redress the violation. Moreover, by allowing the EU to be a party to the proceedings before the ECtHR, the co-respondent mechanism meets one of the objectives of the EU's accession to the Convention, namely to enable the EU to defend the compatibility with the Convention of the act complained of when the ECtHR rules on alleged human rights violations resulting from the implementation of EU law by its Member States. ${ }^{94}$

The applicant in the proceedings before the ECtHR, on the other hand, has the advantage of obtaining, if a Convention violation is found, a judgment which is executable against both the respondent and the co-respondent, ${ }^{95}$ despite the fact that he had to exhaust domestic remedies only in respect of the respondent party.

The ECtHR, for its part, is exempted, by the operation of the co-respondent mechanism, from the difficult task to determine whether the respondent party was competent to act and is to be held responsible for a violation linked to EU law. ${ }^{96}$ The mechanism thus ensures that, in compliance with the principle of autonomy of EU law and the monopoly of the CJEU in interpreting the latter, the ECtHR will not have to determine whether the EU, the Member State(s) or both are to be held responsible, in view of their respective competences, and notably in view of the scope of the margin of appreciation left to the Member States by EU secondary law, for the act at issue, implementing EU law, in the proceedings before it. ${ }^{97}$

Furthermore, the task of the Committee of Ministers in executing the ECtHR's judgments is facilitated. The judgments finding a violation of the Convention will be binding for both the respondent and the co-respondent jointly and in solidarity under Article 46 of the Convention. It will be for the EU and its Member State(s) to determine, in accordance with the procedures provided for by EU law, who has the competence to redress

93 Draft Explanatory Report to the Accession Agreement, doc. CDDH(2011)009 of 14 October 2011, Appendix III, Article 3, § 40.

94 See A.1. above; CDDH Study on EU accession of 2002, ibid., p. 13 (§ 57); and Ladenburger, RTD eur. 47 (1), 2011, p. 21.

95 See also Groussot / Lock / Pech, Legal Assessment of the Draft Accession Agreement, ibid., European Issues $n^{\circ} 218$ (7 November 2011), pp. 12, 13.

96 Ladenburger, RTD eur. 47 (1), 2011, p. 21; and Groussot / Lock / Pech, Legal Assessment of the Draft Accession Agreement, ibid., European Issues n 218 (7 November 2011), p. 13.

97 See De Schutter, L'adhésion de l'UE à la CEDH, ibid., pp. 12, 13, 15; Jacqué, L'adhésion à la CEDH, Hearing by the European Parliament, ibid., §2; Ladenburger, RTD eur. 47 (1), 2011, p. 21; and Groussot / Lock/Pech, Legal Assessment of the Draft Accession Agreement, ibid., European Issues n ${ }^{\circ} 218$ (7 November 2011), p. 10. 
the violation. ${ }^{98}$ It becomes clear from the foregoing that the co-respondent mechanism is therefore not a procedural privilege for the EU or its Member States, but a way to avoid gaps in participation, accountability and enforceability in the Convention system. This corresponds to the very purpose of EU accession and serves the proper administration of justice. ${ }^{99}$

It was considered a major weakness in the co-respondent mechanism, as laid down in the Draft Accession Agreement, that the Contracting Party concerned cannot be obliged to become a co-respondent in the proceedings before the ECtHR. ${ }^{100}$ It is true that the refusal of a Contracting Party to become a co-respondent in cases in which the conditions for the operation of that mechanism are met will frustrate the above aims pursued by that mechanism. However, in a judicial system it appears normal that a Contracting Party cannot be obliged to answer a case which has not been brought against it by the applicant from the outset in compliance with the formal requirements. ${ }^{101}$ Moreover, giving the ECtHR the power to oblige the EU or one of its Member States to join a case could also be seen as a ruling on the allocation of competences between these Contracting Parties. ${ }^{102}$ Whether the EU and its Member States respectively are able to oblige one another to join the proceedings ${ }^{103}$ in accordance with their duty of loyalty is also best for the EU and its Member States to settle among themselves in accordance with an EU-internal procedure. $^{104}$

The foregoing considerations also reveal that a co-respondent mechanism will be of some complexity and will make the procedure before the ECtHR more complicated. The ECtHR, in a given case, might have to deal with up to 28 co-respondents (the EU and all of its Member States) who, moreover, might have joined the proceedings at different stages (but who shall then act jointly before the ECtHR). However, ensuring the EU's participation in the proceedings before the ECtHR via a third-party intervention under Article $36 \S 2$ of the Convention ${ }^{105}$ would not have been a better solution. Up to 27 third-party interveners would equally have made the procedure more burdensome. More importantly, a third party would, legally speaking, not be bound to execute the

98 See CDDH Study on EU accession of 2002, ibid., p. 13 (§ 57); De Schutter, L'adhésion de l'UE à la CEDH, ibid., pp. 12-13; and Callewaert, Accession by the EU to the Convention, ibid., pp. 3-4.

99 Draft Explanatory Report to the Accession Agreement, doc. CDDH(2011)009 of 14 October 2011, Appendix III, Article 3, § 33.

100 Groussot / Lock / Pech, Legal Assessment of the Draft Accession Agreement, ibid., European Issues $n^{\circ} 218$ (7 November 2011), p. 13 .

101 Groussot / Lock / Pech, Legal Assessment of the Draft Accession Agreement, ibid., European Issues $n^{\circ} 218$ (7 November 2011), pp. 13-14, stress in that context that there is little risk for applicants to bring a case against both the EU Member States and the EU as ordinary respondents from the outset after exhaustion of domestic remedies in the Member States' legal order as in many cases there will not be an accessible legal remedy available to the applicant in the EU's legal order.

102 See CDDH Study on EU accession of 2002, ibid., p. 13 (§ 59); and Ladenburger, RTD eur. 47 (1), 2011, p. 24.

103 This was proposed by De Schutter, L'adhésion de l'UE à la CEDH, ibid., pp. 12-13.

104 Compare CDDH Study on EU accession of 2002, ibid., p. 13 (§§59-60); and Ladenburger, RTD eur. 47 (1), 2011, p. 24.

105 See, for instance, Bosphorus, cited above, $\S 9$, in which the Commission participated as a third party. 
ECtHR's judgment. ${ }^{106}$ In any event, on the basis of the relevant case-law of the ECtHR, it is not to be expected that the co-respondent mechanism, which applies only to cases which have been communicated by the ECtHR to the respondent party, will be applied in a large number of cases. ${ }^{107}$

c. Exhaustion of domestic remedies and the necessity of a prior ruling of the CJEU

\section{(1) Scope of the problem}

The interpretation of the requirement of exhaustion of domestic remedies and of the principle of subsidiarity in relation to cases involving EU law (see Article $35 \S 1$ of the Convention) and the necessity of a prior involvement of the CJEU before the ECtHR rules on the Convention compliance of measures based on EU law was one of the most difficult, and possibly one of the most debated, issues to be resolved in the accession negotiations.

Individual applications brought directly against measures taken by EU institutions after accession have to be distinguished in this respect from applications challenging measures taken by national authorities applying or implementing EU law. In cases in which an applicant wants to challenge directly a measure taken by the EU before the ECtHR, exhaustion of domestic remedies will require that he first bring his case before the ECJ or the General Court (ex-CFI) in accordance with the procedures provided for, in particular, in Articles 263 et seq. TFEU, and the involvement of the EU courts in reviewing the compliance of EU acts with fundamental rights thus appears to be secured. ${ }^{108}$

The situation is different in respect of applications which challenge a measure of a Member State authority applying EU law. In that event, the applicant has to exhaust the domestic remedies available before the Member State's courts which, under the conditions set out in Article 267 TFEU and in the CJEU's case-law, may, and in certain cases must refer the case to the CJEU for a preliminary ruling on the validity or interpretation of the EU law applied. In cases in which the Member State's courts refrain from submitting the case to the CJEU, the ECtHR would be called upon to rule on an application concerning the compliance of an EU measure with fundamental rights, without the CJEU having had an opportunity to do so. ${ }^{109}$

106 See also the Draft Explanatory Report to the Accession Agreement, doc. CDDH(2011)009 of 14 October 2011, Appendix III, Article 3, §39; and Groussot / Lock / Pech, Legal Assessment of the Draft Accession Agreement, ibid., European Issues n 218 (7 November 2011), p. 10.

107 Draft Explanatory Report to the Accession Agreement, doc. CDDH(2011)009 of 14 October 2011, Appendix III, Article 3, §§ 44, 45.

108 Compare, for instance, A. Tizzano, Quelques réflexions sur les rapports entre les cours européennes dans la perspective de l'adhésion de l'Union à la Convention, RTD eur. 47 (1), 2011, p. 10.

109 De Schutter, L'adhésion de l'UE à la CEDH, ibid., p. 17; and Draft Explanatory Report to the Accession Agreement, doc. CDDH(2011)009 of 14 October 2011, Appendix III, Article $3, \S 57$. 
The question therefore arises, first, whether a preliminary ruling by the CJEU is a remedy to be exhausted for the purposes of Article $35 \S 1$ of the Convention before bringing such applications to the ECtHR. Under its well-established case-law, the ECtHR requires applicants to exhaust only available and effective remedies. ${ }^{110}$ It is, however, not in the hands of the parties to the proceedings before the Member States' courts to set the preliminary reference procedure in motion, but for the domestic courts alone to decide whether or not they request a preliminary ruling. ${ }^{111}$ In the ECtHR's current case-law, the reference for a preliminary ruling has not been considered an available and effective remedy applicants have to exhaust, and there is a large consensus also among legal writers on that point. ${ }^{112}$ Another option which has been discussed is whether applicants should at least be required, under Article $35 \S 1$ of the Convention, to request that the domestic courts refer the case to the CJEU. ${ }^{113}$ However, it would have to be examined whether this would not also interfere with the interpretation of EU law ${ }^{114}$ and, in any event, this would be a question for the ECtHR to decide after accession when interpreting that Article of the Convention.

In view of this, the CJEU, in its Discussion Document on certain aspects of the accession of the EU to the Convention of May 2010, took the view that, in order to preserve the principle of subsidiarity and to ensure the proper functioning of the judicial system of the Union, a mechanism must be available which is capable of ensuring that the question of the validity of a Union act can be submitted effectively to it before the

110 See, inter alia, Akdivar and Others v. Turkey, 16 September 1996, §§65-66, Reports 1996-IV with further references.

111 See, for instance, Callewaert, Accession by the EU to the Convention, ibid., p. 4; and Groussot / Lock / Pech, Legal Assessment of the Draft Accession Agreement, ibid., European Issues $\mathrm{n}^{\circ} 218$ (7 November 2011), p. 15. It may be noted in this connection that, according to the Court's current case-law, refusal by a domestic court trying a case at final instance to request a preliminary ruling may infringe the right to a fair trial under Article 6 $\S 1$ of the Convention if it appears to be arbitrary (see, inter alia, Divagsa Company $v$. Spain, no. 20631/92, Commission decision of 12 May 1993, Decisions and Reports (DR) 74, p. 274 ; F.S. et N.S. v. France, no. 15669/89, Commission decision of 28 June 1993, DR 75, p. 39; Predil Anstalt S.A. v. Italy (dec.), no. 31993/96, 8 June 1999; Schweighofer and Others v. Austria (dec.), nos. 35673/97, 35674/97, 36082/97 and 37579/97, 24 August 1999; Dotta v. Italy (dec.), no. 38399/97, 7 September 1999; Bakker v. Austria (dec.), no. 43454/98, 13 June 2002; Junnila v. Finland (dec.), no. 62963/00, 13 January 2004; Matheis v. Germany (dec.), no. 73711/01, 1 February 2005; John v. Germany (dec.), no. 15073/03, 13 February 2007; and Abrahamian v. Austria, no. 35354/04, 10 April 2008).

112 Callewaert, Accession by the EU to the Convention, ibid., p. 5. In the Discussion document of the Court of Justice of the European Union on certain aspects of the accession of the European Union to the European Convention for the Protection of Human Rights and Fundamental Freedoms of 5 May 2010, $\S 10$, the CJEU shares this view, as do Skouris, First thoughts on the forthcoming accession of the EU to the ECHR, Essays in Honour of Rozakis, ibid., pp. 565, 567; Tizzano, RTD eur. 47 (1), 2011, p. 10; and Groussot / Lock / Pech, Legal Assessment of the Draft Accession Agreement, ibid., European Issues n 218 (7 November 2011), p. 15, other than Jacqué, L'adhésion à la CEDH, Hearing by the European Parliament, ibid., §2.

113 EP Resolution of 19 May 2010 on EU accession to the Convention, ibid., § 10; Jacqué, L'adhésion à la CEDH, Hearing by the European Parliament, ibid., § 4; and De Schutter, L'adhésion de l'UE à la CEDH, ibid., p. 18.

114 See Callewaert, Accession by the EU to the Convention, ibid., p. 5. 
Strasbourg Court rules on the compatibility of that act with the Convention. ${ }^{115}$ Different procedural means guaranteeing such a prior involvement of the CJEU have been suggested. These include the proposal that the ECtHR itself refer a case pending before it to the CJEU for a preliminary ruling. ${ }^{116}$ Furthermore, CJEU judge C. Timmermans proposed in his personal capacity that a new procedural mechanism be set up allowing the Commission to ask the CJEU to rule on the compatibility of an EU act with fundamental rights once the Strasbourg Court has declared an application before it concerning EU law admissible. The proceedings should be adjourned pending the ruling of the CJEU and terminated in cases where that court finds a violation of fundamental rights by the EU act at issue. ${ }^{117}$

\section{(2) The solution laid down in the Draft Accession Agreement}

The negotiating parties finally agreed on providing for a mechanism allowing for the CJEU to make a prior assessment of the compatibility with fundamental rights of the provision(s) of EU secondary law at issue. ${ }^{118}$

Valuable guidance on this point had previously been given by a Joint Declaration by the Presidents of the CJEU and of the ECtHR of 17 January 2011 summarising the results of the discussion of a meeting of delegations of the two European courts on the question of the possible prior involvement of the CJEU in cases to which the EU is a co-respondent. ${ }^{119}$ In their Joint Declaration, the presidents of the two courts stated that the CJEU and the ECtHR were in favour of establishing a mechanism securing the prior involvement of the CJEU which complies with certain conditions. The mechanism should clearly define the types of cases which were subject to it. It should further ensure the right of the interested parties to assess the consequences of the CJEU's judgment in the proceedings before the ECtHR. Furthermore, the CJEU should give such rulings under the accelerated procedure.

Article $3 \S 6$ of the Draft Accession Agreement can be said to reflect that Joint Declaration. It provides that in proceedings to which the EU is co-respondent, if the CJEU

115 See the CJEU's Discussion document on EU accession to the Convention, ibid., § 12; reproduced (in French), inter alia, in RTD eur. 47 (1), 2011, pp. 35-38. See on this document in detail Skouris, First thoughts on the forthcoming accession of the EU to the ECHR, Essays in Honour of Rozakis, ibid., pp. 562-566.

116 Compare De Schutter, L'adhésion de l'UE à la CEDH, ibid., p. 17.

117 See Timmermans, L'adhésion de l'Union Européenne à la Convention européenne des Droits de l'homme, Hearing on 18 March 2010 by the Committee on Constitutional Affairs of the European Parliament, $\S \S 8-9$. See on that proposal also Skouris, First thoughts on the forthcoming accession of the EU to the ECHR, Essays in Honour of Rozakis, ibid., pp. 566-569; and Tizzano, RTD eur. 47 (1), 2011, p. 11.

118 See for a graphical illustration of that mechanism allowing for the CJEU's prior involvement Groussot / Lock / Pech, Legal Assessment of the Draft Accession Agreement, ibid., European Issues $n^{\circ} 218$ (7 November 2011), p. 14.

119 See Draft Explanatory Report to the Accession Agreement, doc. CDDH(2011)009 of 14 October 2011, Appendix III, § 14; see also O'Boyle, GLJ, vol. 12, 2011, p. 1876; Skouris, First thoughts on the forthcoming accession of the EU to the ECHR, Essays in Honour of Rozakis, ibid., pp. 566, 568; and Tulkens, RTD eur. 47 (1), 2011, p. 33. The Joint Declaration is reproduced (in French), for instance, in RTD eur. 47 (1), 2011, pp. 39-40. 
has not yet assessed the compatibility with the fundamental rights at issue of the provision of EU secondary law, then sufficient time shall be afforded for that court to make such an assessment and thereafter for the parties to make observations to the ECtHR. This prior involvement of the CJEU shall take place before the ECtHR decides on the merits of the case. ${ }^{120}$ It is also understood that the parties involved in the proceedings before the ECtHR would be given the opportunity to make observations in the proceedings before the CJEU. ${ }^{121}$

It is further stipulated in Article $3 \S 6$ of the Draft Accession Agreement that the EU shall ensure that the said assessment is made quickly so that the proceedings before the ECtHR are not unduly delayed. An accelerated procedure already exists before the CJEU. Rulings under that procedure were previously given within 6 to 8 months. ${ }^{122}$

Following the CJEU's ruling, the parties to the proceedings before the ECtHR shall be given the opportunity to assess the consequences of that ruling prior to the ECtHR's examination of the merits of the case. ${ }^{123}$

It is further understood that the provisions of Article $3 \S 6$ of the Draft Accession Agreement shall not affect the powers and jurisdiction of the ECtHR. The CJEU's assessment of the compatibility with fundamental rights of the EU legal basis at issue will thus not bind the ECtHR. ${ }^{124}$

It will thus be for the ECtHR to determine whether, as a result of the CJEU's ruling, the applicant has lost his victim status within the meaning of Article 34 of the Convention. ${ }^{125}$ Under the ECtHR's long-established case-law, a decision or measure favorable to the applicant alone is not, however, sufficient to deprive him of his status as a "victim" for the purposes of Article 34 of the Convention unless the domestic authorities have acknowledged, either expressly or in substance, and then afforded redress for the breach of the Convention. ${ }^{126}$ The question of the applicant's victim status will have to be examined by the ECtHR in the circumstances of the case, having regard, inter alia, to the fact that an EU Member State court's final decision does not, under the current rules, appear to be quashed or the proceedings before that court reopened following the CJEU's ruling.

The ECtHR may further have to examine whether, as a result of a ruling of the CJEU favourable to the applicant, the "matter has been resolved" and the case should be struck

120 Draft Explanatory Report to the Accession Agreement, doc. CDDH(2011)009 of 14 October 2011, Appendix III, Article 3, § 58.

121 Draft Explanatory Report to the Accession Agreement, doc. CDDH(2011)009 of 14 October 2011, Appendix III, Article $3, \S 58$.

122 Draft Explanatory Report to the Accession Agreement, doc. CDDH(2011)009 of 14 October 2011, Appendix III, Article 3, § 61.

123 Draft Explanatory Report to the Accession Agreement, doc. CDDH(2011)009 of 14 October 2011, Appendix III, Article 3, § 61.

124 Draft Explanatory Report to the Accession Agreement, doc. CDDH(2011)009 of 14 October 2011, Appendix III, Article 3, §§ 59-60.

125 See also Groussot / Lock / Pech, Legal Assessment of the Draft Accession Agreement, ibid., European Issues n ${ }^{\circ} 218$ (7 November 2011), p. 16.

126 See, inter alia, Eckle v. Germany, 15 July 1982, §66, Series A no. 51; Scordino v. Italy (no. 1) [GC], no. 36813/97, § 180, ECHR 2006-V; and Gäfgen v. Germany [GC], no. $22978 / 05$, § 115, ECHR 2010-.... 
out of its list of cases under Article $37 \S 1$ (b) of the Convention (with the costs being at the discretion of the ECtHR, see Rule $43 \S 4$ of its Rules of Court).

\section{(3) Assessment}

Objections to the introduction of a "prior involvement" mechanism have been raised, based on the view that such a procedure does not appear necessary as cases in which the Member States' courts fail to comply with their duty to refer a case to the CJEU for a preliminary ruling must be considered as exceptional. ${ }^{127}$ Indeed, an EU-internal solution could also have been envisaged, with the CJEU imposing on Member States' courts an obligation to refer a case to it for a preliminary ruling in cases in which the compliance with the Convention of provisions of EU law is at issue in the proceedings before them. ${ }^{128}$ However, it is clear that this might have led to a sharp increase in cases in which parties invoked the Convention and requests for preliminary rulings were made as a consequence. ${ }^{129}$

More importantly, it has been claimed that creating a special procedure within the Convention system in order to allow the CJEU's prior involvement would accord the CJEU a privileged position compared to the supreme courts of the other Contracting Parties to the Convention. Depending on the domestic rules on procedure, the latter may also not have had an opportunity to give their view prior to the ECtHR's ruling. ${ }^{130}$ As shown above, creating privileges for the EU by amending the Convention system, however, sits uneasily with the principle of equality of the Contracting Parties to the Convention and that of preserving the Convention system. ${ }^{131}$ Treating the Union's legal order differently may, however, be considered justified if it is accepted that the CJEU finds itself in a relevantly different situation in view of its cooperation, in the EU legal system, with the courts of its Member States - different Contracting Parties to the Convention - in the application and interpretation of EU law. ${ }^{132}$

The mechanism allowing for the CJEU to make a prior assessment of the compatibility with fundamental rights of the provision(s) of EU law at issue does, in any event, entail several advantages. Having regard to the principle of subsidiarity, calling for a resolution of cases, wherever possible, at domestic level, it appears highly desirable that the CJEU rules on the compliance with fundamental rights of EU acts before the ECtHR is called

127 This is in fact confirmed by the CJEU in its Discussion document on EU accession to the Convention, ibid., § 10; see also De Schutter, L'adhésion de l'UE à la CEDH, ibid., p. 17.

128 See on this point also Ladenburger, RTD eur. 47 (1), 2011, p. 22, who explains that the prior involvement mechanism allows to make good the breach of the Treaties by the domestic court's omission to refer the case to the CJEU for a preliminary ruling.

129 See Jacqué, RTD eur. 47 (1), 2011, p. 8; compare also Tulkens, RTD eur. 47 (1), 2011, pp. 32, 33.

130 See De Schutter, L'adhésion de l'UE à la CEDH, ibid., p. 17; and Groussot / Lock / Pech, Legal Assessment of the Draft Accession Agreement, ibid., European Issues n 218 (7 November 2011), p. 16.

131 Compare De Schutter, L'adhésion de l'UE à la CEDH, ibid., p. 17; see also the EP Resolution of 19 May 2010 on EU accession to the Convention, ibid., § 15.

132 See also Ladenburger, RTD eur. 47 (1), 2011, p. 22. 
upon to examine their Convention compliance. ${ }^{133}$ Having regard to the arrangements made, it can be expected that that procedure would not unduly prolong the proceedings before the ECtHR. ${ }^{134}$ Moreover, the ECtHR will subsequently have the benefit of the CJEU's interpretation of the contested EU act for its own examination of the compatibility with the Convention of a measure based on that act. ${ }^{135}$ Provided that the CJEU also gave its view on the distribution of competences between the EU and its Member States in relation to the act at issue, the ECtHR's task in reasoning its decision on an alleged Convention violation in relation to the respondent and co-respondent parties before it will also be facilitated. The prior involvement of the CJEU in a case already pending before the ECtHR would, furthermore, foster the dialogue between those courts, in the interest of the protection of fundamental rights at European level.

Moreover, what is important from the ECtHR's perspective is that its powers and jurisdiction have equally been respected in the prior involvement mechanism. It remains notably in the ECtHR's competence to determine, in accordance with the Convention and its case-law, how to proceed with the application before it following the CJEU's involvement.

It is to be noted, finally, that the exact procedure to be used to organize the CJEU's prior involvement has not been laid down in the Accession Agreement. It was left to the EU to decide, in particular, whether the ECtHR should be allowed to make a reference to the CJEU where the EU is a co-respondent to an application pending before it or whether the European Commission should be entrusted to ask the CJEU for a prior ruling. ${ }^{136}$

\section{d. Inter-"State"-cases (Article 33 of the Convention)}

According to the principle of autonomy of EU law, which is notably reflected in Article 344 TFEU, disputes concerning the interpretation or application of EU law may not be submitted to any external procedure of settlement, but must be settled in accordance with the methods of settlement provided for in the Treaties. ${ }^{137}$ Inter-party applications between EU Member States or between EU Member States and the EU itself under Article 33 of the Convention within the scope of EU law would therefore circumvent

133 See on the importance of a « healthy subsidiarity » also D. Spielmann, Dans l'esprit d'Interlaken: quels droits fondamentaux pour la Constitution luxembourgeoise?, in Dalloz (editor), La conscience des droits, Mélanges en l'honneur de Jean-Paul Costa, 2011, p. 586.

134 See on that concern Tulkens, Les aspects institutionnels de l'adhésion de UE à la CEDH, ibid., p. 4; Jacqué, L'adhésion à la CEDH, Hearing by the European Parliament, ibid., § 4; De Schutter, L'adhésion de l'UE à la CEDH, ibid., p. 17; and Groussot / Lock / Pech, Legal Assessment of the Draft Accession Agreement, ibid., European Issues n ${ }^{\circ} 218$ (7 November 2011), p. 16.

135 See also Skouris, First thoughts on the forthcoming accession of the EU to the ECHR, Essays in Honour of Rozakis, ibid., pp. 568-569; and Ladenburger, RTD eur. 47 (1), 2011, p. 26.

136 Groussot / Lock / Pech, Legal Assessment of the Draft Accession Agreement, ibid., European Issues n ${ }^{\circ} 218$ (7 November 2011), pp. 15-16; and N. O'Meara, "A More Secure Europe of Rights?" The European Court of Human Rights, the Court of Justice of the European Union and EU Accession to the ECHR, GLJ, vol. 12, 2011, pp. $1824 \mathrm{~s}$.

137 See B.3.a. above; and Article 3 of Protocol (no. 8) relating to Article $6 \S 2$ TEU. 
the settlement mechanisms provided for in the Treaties. ${ }^{138}$ It did not, however, appear indispensable to address this issue in the Accession Agreement as the EU and its Member States could equally regulate the matter in an agreement between themselves. ${ }^{139}$

Article 4 of the Draft Accession Agreement is accordingly limited to amending Articles $29 \S 2$ and 33 of the Convention to refer to "inter-Party" (instead of "inter-State") applications and cases respectively. From a Convention perspective, following the EU's accession, all States party to the Convention could therefore bring a case against the EU, and vice versa. ${ }^{140}$

\section{e. Interpretation of certain Articles of the Convention in relation to the EU}

Under Article $35 \S 2$ (b) of the Convention, the ECtHR shall not deal with an individual application concerning a matter which has already been submitted to "another procedure of international... settlement". As, following accession, the position of the EU courts would be analogous to that of the domestic courts of the other Contracting Parties, any previous proceedings before the Union courts could, however, not be regarded as "another procedure of international settlement" for the purposes of the said Article which would render an application before the ECtHR inadmissible. ${ }^{141}$ Article 5 of the Draft Accession Agreement clarifies this and confirms that proceedings before the CJEU shall be considered as not constituting a procedure of international investigation or settlement within the meaning of Article $35 \S 2$ (b) of the Convention. ${ }^{142}$

Furthermore, Article 55 of the Convention only excludes external means of settlement for disputes arising out of the interpretation or application of the Convention. Therefore, it does not appear to prejudice the internal settlement procedures for disputes relating to the application of Union law before the Union courts. ${ }^{143}$ Article 5 of the Draft Accession Agreement clarifies that proceedings before the CJEU do not constitute means of dispute settlement within the meaning of Article 55 of the Convention with respect to EU Member States. ${ }^{144}$ Thereby, a potential conflict between Article 344 TFEU and Article 55 of the Convention has been avoided in cases in which EU Member States brought proceedings against each other before the CJEU which concern, inter alia, provisions of the Convention. ${ }^{145}$

138 See in more detail De Schutter, L'adhésion de l'UE à la CEDH, ibid., p. 16.

139 See CDDH Study on EU accession of 2002, ibid., pp. 14-15 (§§ 63-65); and EP Resolution of 19 May 2010 on EU accession to the Convention, ibid., $\S 8$.

140 Draft Explanatory report to the Agreement on the Accession of the European Union to the Convention for the Protection of Human Rights and Fundamental Freedoms, doc. CDDH(2011)009 of 14 October 2011, Appendix III, Article 4, §§ 62-64.

141 Compare the CDDH Study on EU accession of 2002, ibid., pp. 11/12 (§§ 48-49).

142 See for further details the Draft Explanatory Report to the Accession Agreement, doc. CDDH(2011)009 of 14 October 2011, Appendix III, Article 5, § 65.

143 See, however, Lock, Law and Practice of International Courts and Tribunals 8 (2009), pp. 387 ss.

144 See for further details the Draft Explanatory Report to the Accession Agreement, doc. CDDH(2011)009 of 14 October 2011, Appendix III, Article 5, § 66.

145 Groussot / Lock / Pech, Legal Assessment of the Draft Accession Agreement, ibid., European Issues $n^{\circ} 218$ (7 November 2011), p. 10. 
As shown above, it was further clarified that the EU will not have a right to intervene as a third party under Article $36 \S 1$ of the Convention in all cases before the ECtHR lodged by its citizens and "nationals" of EU Member States. This results from the noninclusion of the term "nationals" in Article 36 of the Convention in the interpretation clause laid down in the new version of Article $59 \S 2$ of the Convention, as amended by Article $1 \S 2$ of the Draft Accession Agreement. ${ }^{146}$

\section{f. Expected consequences of the accession on the ECtHR's workload}

It is to be expected that the additional workload for the ECtHR following EU accession will be rather modest, given that only the decisions taken by the Union courts on the merits will be added to the acts which may be challenged before the ECtHR. As shown above, national courts' judgments concerning EU law, possibly following a preliminary ruling by the CJEU, fall under the ECtHR's jurisdiction already now. ${ }^{147}$

Moreover, as a Contracting Party to the Convention, the EU will also become responsible for the proper functioning of the Convention system and is called upon, together with all Contracting Parties, to support the ECtHR in its relentless attempt to deal with the ever increasing number of applications within a reasonable time. ${ }^{148}$

\section{Representation of the EU in bodies of the Convention and financial contribution}

a. Participation and election of an EU judge

Under Article 20 of the Convention, a judge shall be elected with respect to each High Contracting Party. There has, therefore, been broad agreement that an EU judge appointed only on an ad hoc basis or participating only in cases involving EU law (in view of the fact that there were already 27 judges appointed in respect of the EU Member States) was not a true option. ${ }^{149}$ The judge elected in respect of the EU shall have the same status and duties as the other judges and participate equally in the ECtHR's work. ${ }^{150}$ Indeed, a full-time EU judge participating on an equal footing with other judges is in line with the spirit of the Convention system. ${ }^{151}$ It secures the representation of and

146 See B.2.b. above.

147 See B.3.a. above; Tulkens, Les aspects institutionnels de l'adhésion de UE à la CEDH, ibid., p. 4; Tulkens, RTD eur. 47 (1), 2011, p. 33; Callewaert, Accession by the EU to the Convention, ibid., p. 6; and Groussot/Lock/Pech, Legal Assessment of the Draft Accession Agreement, ibid., European Issues n ${ }^{\circ} 218$ (7 November 2011), p. 17.

148 Compare Tulkens, Les aspects institutionnels de l'adhésion de UE à la CEDH, ibid., p. 5; Tulkens, RTD eur. 47 (1), 2011, p. 33; and Callewaert, Accession by the EU to the Convention, ibid., p. 7.

149 See for these options in detail the CDDH Study on EU accession of 2002, ibid., pp. 15-16 (§§ 66-74).

150 Draft Explanatory Report to the Accession Agreement, doc. CDDH(2011)009 of 14 October 2011, Appendix III, Article 6, § 69. See also Article 1 (a) of Protocol (no. 8) relating to Article 6 \& 2 TEU.

151 See also Groussot / Lock / Pech, Legal Assessment of the Draft Accession Agreement, ibid., European Issues n ${ }^{\circ} 218$ (7 November 2011), p. 8. 
the availability of expertise on the EU legal system ${ }^{152}$ and contributes to the legitimacy of the ECtHR's decisions by a participation of each Contracting Party in the system of collective enforcement set up by the Convention. ${ }^{153}$

In accordance with that principle of participation on an equal footing, the Parliamentary Assembly of the Council of Europe (PACE, composed of 318 members of parliament appointed by the national parliaments of the Council of Europe's Member States) shall elect the judge sitting in respect of the EU in accordance with the procedure prescribed in Article 22 of the Convention. Article 6 of the Draft Accession Agreement provides in that connection that a delegation of the European Parliament shall be entitled to participate, with the right to vote, in the sessions of the PACE (and its relevant bodies $)^{154}$ when the latter exercises its functions related to the election of judges under Article 22 of the Convention. ${ }^{155}$

This necessity for a special (and reasonable) regulation arises from the fact that the EU will not become a Member of the Council of Europe and would not, therefore, be represented in the PACE otherwise. This arrangement thus allows the EU to participate in the bodies of the $\mathrm{CoE}$ when the latter exercise functions relating to the Convention system. ${ }^{156}$ The number of representatives of the European Parliament shall be the same as the highest number of representatives to which any State is entitled (see Article 26 of the Statute of the Council of Europe; currently 18 representatives). ${ }^{157}$ The modalities for the European Parliament's participation in the work of the PACE shall be defined by the latter in co-operation with the European Parliament. ${ }^{158}$

\section{b. EU representation in the Committee of Ministers}

Under Article $7 \S 1$ of the Draft Accession Agreement, the EU shall be entitled to participate, with the right to vote, in the Council of Europe's Committee of Ministers (CM) when the latter takes decisions concerning its functions in relation to the Convention. Most importantly, the EU shall have a right to vote when the Committee of Ministers supervises the execution of the ECtHR's final judgments (see Article $46 \S \S 2$ to 5 of the Convention) and of the terms of friendly settlements effected before it (see Article 39

152 See on this point also Groussot / Lock / Pech, Legal Assessment of the Draft Accession Agreement, ibid., European Issues n 218 (7 November 2011), p. 3.

153 See CDDH Study on EU accession of 2002, ibid., pp. 15, $16(\S \S 67,73)$; see also Jacqué, L'adhésion à la CEDH, Hearing by the European Parliament, ibid., § 3; and De Schutter, L'adhésion de l'UE à la CEDH, ibid., p. 18.

154 Draft Explanatory Report to the Accession Agreement, doc. CDDH(2011)009 of 14 October 2011, Appendix III, Article 6, §67.

155 See also EP Resolution of 19 May 2010 on EU accession to the Convention, ibid., § 7.

156 See also Groussot / Lock / Pech, Legal Assessment of the Draft Accession Agreement, ibid., European Issues n 218 (7 November 2011), pp. 3, 8 .

157 See also Groussot / Lock / Pech, Legal Assessment of the Draft Accession Agreement, ibid., European Issues n 218 (7 November 2011), p. 8; and J. Králová, Comments on the Draft Agreement on the Accession of the European Union to the Convention for the Protection of Human Rights and Fundamental Freedoms, CYIL 2 (2011), p. 140.

158 Draft Explanatory Report to the Accession Agreement, doc. CDDH(2011)009 of 14 October 2011, Appendix III, Article 6, § 68 . 
$\S 4$ of the Convention). ${ }^{159}$ The necessity to regulate this issue equally arose because, under Article 14 of the Statute of the CoE, only Member States may vote in the Committee of Ministers with one vote each and the EU will not become a member of the Council of Europe. ${ }^{160}$

The negotiators of the agreement noted, however, that in certain circumstances, the EU treaties obliged the EU and its Member States to express positions and vote in a coordinated manner. This is the case (only) where the CM supervises the fulfilment of obligations either by the EU alone, or by the EU and one or more of its Member States jointly - that is, in cases in which the EU has been either respondent or co-respondent. ${ }^{161}$ It was agreed that in these circumstances, the exercise of the right to vote by the EU and its Member States may not prejudice the effective exercise by the CM of its supervisory functions under Articles 39 and 46 of the Convention. ${ }^{162}$ Without a change in the voting rights, the EU and its Member States would in fact have accounted for a majority of 28 of the then 48 Contracting Parties having a right to vote in the CM and would, therefore, have had a decisive influence on decisions relating to the execution of judgments against them. ${ }^{163}$

Article $7 \S 2$ (a) of the Draft Accession Agreement therefore stipulates that special voting rules shall be introduced in this respect. In accordance with that provision, the CDDH proposed to the CM to add a Rule (Rule 18) to the Rules of the Committee of Ministers for the supervision of the execution of judgments and of the terms of friendly settlements, ${ }^{164}$ concerning judgments and friendly settlements in cases to which the EU is a party. ${ }^{165}$ That draft Rule provides that, as a general rule, where the CM supervises the fulfilment of obligations either by the EU, or by the EU and one or more of its Member States jointly, the Contracting Parties shall consider decisions by the $\mathrm{CM}$ as

159 Under Article $7 \S 1$ of the Draft Accession Agreement, ibid., the EU shall further have a right to vote when the Committee of Ministers takes a decision reducing the number of judges of the ECtHR's Chambers (Article $26 \S 2$ of the Convention) or requesting the ECtHR to give an advisory opinion (Article 47 of the Convention). Moreover, the EU shall participate in the Committee of Ministers' decisions regarding the adoption of Protocols to the Convention or of any other instrument or text relating to the Convention system, see also Draft Explanatory Report to the Accession Agreement, doc. CDDH(2011)009 of 14 October 2011, Appendix III, Article 7, §§ 70-71.

160 Groussot / Lock / Pech, Legal Assessment of the Draft Accession Agreement, ibid., European Issues $n^{\circ} 218$ (7 November 2011), p. 8; and Králová, CYIL 2 (2011), p. 140. See on this issue already the CDDH Study on EU accession of 2002, ibid., pp. 9/10 (§§ 35-38); and De Schutter, L'adhésion de l'UE à la CEDH, ibid., pp. 18-19.

161 See also Draft Explanatory Report to the Accession Agreement, doc. CDDH(2011)009 of 14 October 2011, Appendix III, Article 7, § 75; and Králová, CYIL 2 (2011), p. 141.

162 Draft Explanatory Report to the Accession Agreement, doc. CDDH(2011)009 of 14 October 2011, Appendix III, Article 7, § 73.

163 See also Groussot / Lock / Pech, Legal Assessment of the Draft Accession Agreement, ibid., European Issues n ${ }^{\circ} 218$ (7 November 2011), pp. 8-9.

164 Rules adopted by the Committee of Ministers at its $964^{\text {th }}$ meeting on 10 May 2006, see http://www.coe.int/t/dghl/monitoring/execution/Source/Documents/Docs_a_propos/CMrules2006 en.pdf.

165 See $C D D \bar{H}$ Report to the Committee of Ministers on the elaboration of legal instruments for the accession of the European Union to the European Convention on Human Rights, doc. CDDH(2011)009 of 14 October 2011, Appendix II. 
adopted if a simple majority of the representatives entitled to sit on the CM on behalf of those Contracting Parties that are not EU Member States is in favour (draft Rule 18 (a)). ${ }^{166}$

These specific provisions, which give the non-EU Member States a decisive role in adopting resolutions concerning the execution of judgments against the EU, shall not, however, be seen as a departure from the established practice that decisions in the Committee of Ministers are adopted by consensus, with formal votes only exceptionally being taken. ${ }^{167}$

\section{c. Financial contribution by the EU}

Under Article 8 of the Draft Accession Agreement, the EU shall pay an annual contribution dedicated to the expenditure related to the functioning of the Convention. That expenditure comprises the expenditure on the ECtHR, on the supervision of the execution of its judgments and on the functioning, when performing functions under the Convention, of the Committee of Ministers, the Parliamentary Assembly and the Secretary General of the Council of Europe and administrative overhead costs. ${ }^{168}$ The amount of this contribution shall be equal to $34 \%$ of the highest amount contributed in the previous year by any State to the Ordinary Budget of the Council of Europe. ${ }^{169}$ That percentage reflects the amount within the Council of Europe's budget dedicated to the functioning of the Convention system in the previous years and the figures foreseen for the two years to come. ${ }^{170}$

166 See for the specific voting rules applicable to decisions by the Committee of Ministers concerning referrals to the ECtHR for interpretation of a judgment and infringement proceedings draft Rule 18 (b) and for the specific voting rule applicable to final resolutions of the Committee of Ministers draft Rule 18 (c) of the Rules of the Committee of Ministers for the supervision of the execution of judgments and of the terms of friendly settlements. See further Draft Explanatory Report to the Accession Agreement, doc. CDDH(2011)009 of 14 October 2011, Appendix III, Article 7, §§ 76-78.

167 Draft Explanatory Report to the Accession Agreement, doc. CDDH(2011)009 of 14 October 2011, Appendix III, Article 7, § 74. See also Králová, CYIL 2 (2011), pp. 141-142.

168 See Article $8 \S 3$ of the Draft Accession Agreement, ibid.

169 See Article $8 \S 1$ of the Draft Accession Agreement, ibid. Under Article 50 of the Convention, the expenditure of the ECtHR is borne by the Council of Europe. The budget of the ECtHR and of the other entities involved in the functioning of the Convention system is part of the Council of Europe's Ordinary Budget. In 2011, the EU would have been liable to pay, under this provision, EUR 9.34 million (its own budget for 2011 amounting to EUR 141.9 billion), see Draft Explanatory Report to the Accession Agreement, doc. CDDH(2011)009 of 14 October 2011, Appendix III, Article 8, $\S 82$ and 85, footnote 29; and Groussot / Lock/ Pech, Legal Assessment of the Draft Accession Agreement, ibid., European Issues n 218 (7 November 2011), p. 9.

170 Draft Explanatory Report to the Accession Agreement, doc. CDDH(2011)009 of 14 October 2011, Appendix III, Article 8, $\S 84$ and 86-87. A safeguard clause is laid down in the Article $8 \S 2$ of the Draft Accession Agreement allowing, in particular, for an adjustment of the above percentage if the amount dedicated within the Council of Europe's budget to the expenditure related to the functioning of the Convention deviates considerably (by more than 2.5 percentage points in each of two consecutive years) from the said figure. 


\section{Concluding remarks}

Having regard to the various provisions of the Draft Accession Agreement, it can be concluded that a well-balanced text has been worked out within quite a short period of time. In line with the guiding principles for the accession negotiations, the Convention text shall be amended only to a relatively small extent. Its readability shall be maintained by making references to the Accession Agreement and by including general interpretative clauses instead of amending numerous Articles of the Convention.

It is further clear that the two main new elements contained in the Accession Agreement, the co-respondent mechanism and the prior involvement of the CJEU, will render the Convention system for the protection of fundamental rights a little more complex. What is decisive, however, is that - as has been shown above - both the CJEU's competence to interpret EU law authoritatively and the ECtHR's competence to interpret the Convention appear to have been fully respected in the agreement. As there is nothing to suggest that the relationship between these two courts will not be characterized by cooperation and mutual trust, ${ }^{171}$ the EU's accession to the Convention under that Agreement will strengthen the protection of fundamental rights in Europe.

In view of the complex procedure for the adoption and ratification of the Accession Agreement, many hurdles still have to be cleared on the long way to accession. But the Draft Accession Agreement has been a major and promising step on that path.

171 See also Tizzano, RTD eur. 47 (1), 2011, p. 12. 